\title{
Uselessness of radiological differentiation of oncocytoma and renal cell carcinoma in management of small renal masses
}

\author{
Teresa Pusiol • Maria Grazia Zorzi · Doriana Morichetti · \\ Irene Piscioli • Michele Scialpi
}

Received: 16 March 2011 / Accepted: 2 May 2011 / Published online: 21 May 2011

(C) The Author(s) 2011. This article is published with open access at Springerlink.com

In the paper "Differentiation of oncocytoma and renal cell carcinoma in small renal masses $(<4 \mathrm{~cm}$ ): the role of 4-phase computerized tomography" published online August 18, 2010, in World Journal of Urology, Bird V.G. and colleagues [1] write in the Discussion: "With the advancement of imaging techniques, enhancement patterns of renal tumors on CT have evolved to be the best, though limited, non-invasive technique to predict the pathological diagnosis of renal tumors. Implementing this technique to differentiate oncocytoma from the subtypes of RCC will have a great impact on the management of patients. In conclusion, non-invasive differentiation between benign and malignant renal tumors has paramount importance in determining the management plan for patients."We do not agree with these statements. The small renal masses (SRMs) may

\footnotetext{
T. Pusiol $(\bowtie) \cdot$ M. G. Zorzi · D. Morichetti

Institute of Anatomic Pathology, Rovereto Hospital,

P.le S. Maria, 7, 38068 Rovereto, Italy

e-mail: teresa.pusiol@apss.tn.it

M. G. Zorzi

e-mail: mariagrazia.zorzi2@apss.tn.it

D. Morichetti

e-mail: doriana.morichetti@apss.tn.it

I. Piscioli

Department of Radiology, Budrio Hospital, Budrio,

Bologna, Italy

e-mail: irenedelirium@libero.it

M. Scialpi

Department of Surgical, Radiologic and Odontostomatologic

Sciences, Section of Diagnostic and Interventional Radiology,

S. Maria della Misericordia Hospital,

S. Andrea delle Fratte, Perugia, Italy

e-mail: michelescialpi@libero.it
}

be defined as neoplastic lesions $<4 \mathrm{~cm}$ in diameter, which are more and more often found, especially in elderly and comorbid patients. Today, the vast majority of SRMs are incidentally diagnosed and therefore tend to have a better prognosis [2-4]. Nephron-sparing surgery (NSS) is the standard care for SRMs (stage pT1a). Patients with SRMs who are treated with NSS exhibit similar recurrence-free (0-3\%) and 5-year cancer-specific survival when compared with renal nefrectomy [5-9]. SRMs include malignant and benign tumors. In the urologic practice, all SRMs should be removed with NSS independently from their histological nature. We believe that the differentiation of oncocytoma and renal cell carcinoma in SRMs is unnecessary because the tumor should be removed with NSS independently of its histological nature. Non-invasive differentiation between benign and malignant renal tumors has paramount importance in determining the management plan for patients only when the tumor is $>4 \mathrm{~cm}$ in diameter.

\section{Conflict of interest None}

Open Access This article is distributed under the terms of the Creative Commons Attribution Noncommercial License which permits any noncommercial use, distribution, and reproduction in any medium, provided the original author(s) and source are credited.

\section{References}

1. Bird VG, Kanagarajah P, Morillo G et al (2010) Differentiation of oncocytoma and renal cell carcinoma in small renal masses $(<4 \mathrm{~cm})$ : the role of 4-phase computerized tomography. World J Urol. August 18

2. Hollingsworth JM, Miller DC, Daignault S et al (2006) Rising incidence of small renal masses: a need to reassess treatment eVect. J Natl Cancer Inst 98:1331-1334

3. Jayson M, Sanders A (1998) Increased incidence of serendipitously discovered renal cell carcinoma. Urology 51:203-205 
4. Luciani LG, Gestari R, Tallarigo C (2000) Incidental renal cell carcinoma-age and stage characterization and clinical implications: study of 1092 patients (1982-1997). Urology 56:58-62

5. Aron M, Gill IS (2007) Minimally invasive nephron-sparing surgery (MINSS) for renal tumours: Part II: probe ablative therapy. Eur Urol 51:348-357

6. Kunkle DA, Egleston BL, Uzzo RG (2008) Excise, ablate or observe: the small renal mass dilemma-a meta-analysis and review. J Urol 179:1227-1233
7. Lee CT, Katz J, Shi W et al (2000) Surgical management of renal tumors $4 \mathrm{~cm}$ or less in a contemporary cohort. J Urol 163:730-736

8. Uzzo RG, Novick AC (2001) Nephron-sparing surgery for renal tumors: indications, techniques and outcomes. J Urol 166:6-18

9. Delakas D, Karyotis I, Daskalopoulos G et al (2002) Nephron-sparing surgery for localized renal cell carcinoma with a normal contralateral kidney: a European three-centre experience. Urology 60:998-1002 